Amarasinghe, S.D.I.A. and Chandani, H., 2019. Essential stakeholder contributions for establishing Life Cycle Assessment (LCA) in the construction industry: A desk study. In: Sandanayake, Y.G., Gunatilake, S. and Waidyasekara, A. (eds). Proceedings of the $8^{\text {th }}$ World Construction Symposium, Colombo, Sri Lanka, 8-10 November 2019, pp. 320-329. DOI: doi.org/10.31705/WCS.2019.32. Available at: https://2019.ciobwcs.com/papers

\title{
ESSENTIAL STAKEHOLDER CONTRIBUTIONS FOR ESTABLISHING LIFE CYCLE ASSESSMENT (LCA) IN THE CONSTRUCTION INDUSTRY: A DESK STUDY
}

\author{
S.D.I.A. Amarasinghe ${ }^{1}$ and Chandanie Hadiwattage ${ }^{2}$
}

\begin{abstract}
In recent times, Life Cycle Assessment (LCA) has been evolved in globally as an analytical tool that systematically and holistically investigates cumulative environmental impacts associated with the entire building lifecycle from its cradle-to grave. Moreover, LCA approach has become a well-rooted concept internationally as a decision making tool due to the collaborative activities between main five (05) stakeholders i.e. academia, government, construction industry, civil society, and the natural environment. In contrast, it is difficult to find evidence on the application of LCA in Sri Lankan construction industry. Also, there is increasing interest in applying LCA, as Sri Lankan construction industry has been criticised due to the environmental pollution with the escalation of upcoming building projects. Hence, this study aimed to conduct a desk study by reviewing existing literature to disclose the activities, which the developed countries followed to integrate LCA into construction practice pertaining to aforesaid five stakeholder's contributions. Literature findings highlighted that, academia have to undertake and disseminate fact-based and comprehensive research on the field of LCA in order to popularize the concept of LCA while government bodies, construction industry, civil society and natural environment have to take actions to embed LCA to the environmental regulations and environmental planning as a core element to take voluntary actions to build ecologically sustainable constructions by using LCA as a decision making technique. Environmental modeling software packages have to be introduced as a collaborative activity of academia, construction industry and natural environment to make it possible to integrate LCA to the construction industry.
\end{abstract}

Keywords: Academia; Civil Society; Construction Industry; Government; Life Cycle Assessment; Natural Environment.

\section{INTRODUCTION}

At present, building constructions have become a foremost threat for environment, as the construction sector accounts for 40\% energy consumption, 33\% of GHG (Green House Gas) emissions, $30 \%$ of raw material usage, $25 \%$ of water consumption, $25 \%$ of solid waste generation and $12 \%$ of land use globally (Mills, 2009). Due to the speedy developments in the construction industry, the upward trend in adverse environmental

\footnotetext{
${ }^{1}$ Department of Building Economics, University of Moratuwa, Sri Lanka, ra-isuri@uom.lk

${ }^{2}$ Department of Building Economics, University of Moratuwa, Sri Lanka, chandanieh@uom.lk
} 
influences will continue in the future (Robertson et al., 2012), along with critical economic and social influences.

In order to address these challenges, ecological considerations (i.e. energy saving, reduction of material usage, reduction of construction waste generation and emissions control, etc.) are required to be amalgamated into decisions made by a variety of parties (i.e. contractors, consultants, engineers, government bodies, general public, environmentalists, etc.), who are involved in the process of building constructions (Eckerberg and Nilsson, 2013). Subsequently, different methods and tools have come into practice which address the aforesaid ecological considerations to alleviate undesirable environmental problems (Atmaca, 2016). Examples include LCA, Environmental Impact Assessment (EIA) and Ecological Footprint, etc. (Buyle et al., 2013).

Amongst, aforementioned tools, Basbagill et al. (2013) have found that, the LCA can be applied to construction industry in order to predict, how a building or any other structure would perform throughout its lifetime. Moreover, LCA can be defined as a systematic set of processes, which targets to quantitatively evaluate the potential environmental burdens affixed with building lifecycle by recognizing and quantifying all environmental inputs (i.e. raw material, water and energy) and environmental outputs (i.e. atmospheric emissions, solid waste generation and waterborne waste) (Chau et al., 2015).

On the other hand, LCA seems to be utilised rapidly in developed countries with increased attention towards constructing more environmentally friendly constructions (Guinee et al., 2011). Confirming the above view, LCA has been mostly engaged in the construction sector in developed countries such as; Europe, North America, Japan, and Korea (Islam et al., 2015). Supportively, prevailing literature indicates significant evidence of an extensive amount of LCA being conducted in developed counties rather than in developing countries (Ortiz et al., 2009). It can be proved that, LCA has been successfully integrated in the construction industry in developed countries as a result of collaborative activities between main five (05) stakeholders such as; academia, government, construction industry, civil society, and the natural environment (Szalay, 2007). Accordingly, required contribution from aforementioned five (05) stakeholders to integrate LCA to the construction industry in developing countries successfully, is worthy to be examined.

\section{RESEARCH METHODOLOGY}

Desk study research method is selected to achieve the aim of this research. A desk study can be identified as searching information using prevailing resources such as; published papers, analytical reports and other publications (Crisp, 1981). Moreover, a desk study can be identified as a secondary data used research method, which is used to review previous research findings for the purpose of gaining a comprehensive understanding on a relevant research field (Bingham et al., 2012). When consider about the aim of this research, desk study was carried out to identify essential contributions from stakeholders (i.e. academia, government, construction industry, civil society, and the natural environment) to establish LCA enabled construction industry in the local context. Hence, a thorough review of the existing literature published in the last ten (10) years on LCA was undertaken. Thereafter, results of the study are significant since it recognizes the essential contributions of aforesaid stakeholders to establish LCA in the construction industry in a developing country like Sri Lanka. 


\section{LITERATURE REVIEW}

\subsection{INCORPORATING CYCLE ASSESSMENT INTO CONSTRUCTION INDUSTRY PRACTICE}

LCA can be identified as an analytical method that systematically and holistically investigates, compiles and evaluates potential environmental burdens attributed with products, processes or an activity by ascertaining and quantifying material usage, energy consumption and environmental releases during the lifecycle of the product (Rønning and Brekke, 2014). Implementation of LCA is ruled by ISO 14041-14043 standards and the implementation process is structured into four fundamental steps such as, Goal and Scope Definition, Life Cycle Inventory (LCI), Life Cycle Impact Assessment (LCIA), and Interpretation (Chau et al., 2015). Moreover, LCA enables the quantification of cumulative environmental impacts attached along the entire life cycle from "cradle to grave" (Rønning and Brekke, 2014). LCA allows to prioritise, optimisation efforts based on an accurate information, so LCA is driven to the construction industry by incorporating proactive ecological concerns such as design and management implications which is able to optimize resource usage, energy consumption and waste generation over the entire lifecycle (Zhang et al., 2014). Accordingly, with the use of LCA, decision-makers can take the decisions that will resultant least negative impacts into the environment to create sustainable world (Fedkin, 2017).

However, existing literature shows significant evidences that an extensive amount of LCA have been conducted in developed counties rather than in developing countries (Ortiz et al., 2009; Saunders et al., 2013). Confirming the above view, LCA has been mostly engaged in the construction sector in developed countries such as; Europe, North America, Japan, and Korea (Islam et al., 2015). Accordingly, it was proved that LCA is not a novel concept in the developed countries (Edirisinghe, 2013). Number of studies have divulged various reasons that encourage the adoption of LCA to the construction industry in developed countries, Dewulf et al. (2009) highlighted that construction industry in developed countries actively participate in organising workshops, publishing scientific papers and several handbooks (i.e. International Reference Life Cycle Data System Handbook (ILCD)) on LCA, which encourage the application of LCA within construction industry. Moreover, government bodies promote the utilisation of LCA by incorporating LCA into policies and regulations such as Construction Products Regulation (CPR), European Commission on Integrated Product Policy (IPP) and in the certification schemes for sustainable building constructions (Kogler and Goodchild, 2017). Szalay (2007) further elaborated that, academia, government, construction industry and environmentalists are collaboratively involved in developing different LCA data bases such as ATHENA for US and Canada and GaBi and SimaPro for Europe to facilitate LCA in redeveloped countries. Increasing awareness on environmental sustainability coupled with pressures from numerous stakeholders such as government, environmental activist and civil society to protect environment have keen in introducing LCA (Singh et al., 2010). It is proved that, LCA has been successfully integrated in the construction industry in developed countries as a result of collaborative activities between main five (05) stakeholders such academia, government, construction industry, civil society, and the natural environment. Hence, it is very much critical to further identify the essential contributions from aforementioned stakeholders in order to implement LCA 
within construction industry. Table 1 indicates the identification of a contribution from stakeholders to integrate LCA for the construction industry.

Table 1: Contribution from stakeholders to establish LCA for the costruction industry

\begin{tabular}{|c|c|c|c|c|c|c|}
\hline \multirow[t]{2}{*}{$\begin{array}{l}\text { Required contributions from stakeholders to establish } \\
\text { LCA for the construction industry }\end{array}$} & \multicolumn{5}{|c|}{$\begin{array}{c}\text { Responsible } \\
\text { Stakeholders }\end{array}$} & \multirow[t]{2}{*}{$\begin{array}{l}\text { Reference } \\
\text { Code }\end{array}$} \\
\hline & 递 & 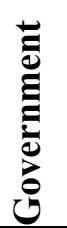 & 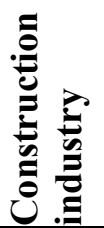 & 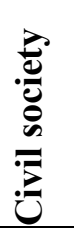 & 童 & \\
\hline $\begin{array}{l}\text { Integration of LCA into an environmental policy, } \\
\text { legislation and environmental planning as a motivation } \\
\text { mechanism to promote sustainable development }\end{array}$ & & $\checkmark$ & $\checkmark$ & & $\checkmark$ & $3,10,14$ \\
\hline Encourage the use of LCA & $\sqrt{ }$ & $\checkmark$ & $\checkmark$ & $\checkmark$ & $\sqrt{ }$ & 10 \\
\hline Organization of workshops and forums on LCA & $\checkmark$ & $\checkmark$ & $\checkmark$ & $\checkmark$ & $\checkmark$ & 10 \\
\hline $\begin{array}{l}\text { Standardisation of LCA guides and handbooks specially } \\
\text { for construction industry }\end{array}$ & $\checkmark$ & $\checkmark$ & $\checkmark$ & & & $9,10,12$ \\
\hline $\begin{array}{l}\text { Organization of platform to co- ordinate LCA } \\
\text { practitioners, scientists, and users, for the continuous } \\
\text { improvement of LCA }\end{array}$ & $\checkmark$ & $\checkmark$ & $\checkmark$ & $\checkmark$ & $\checkmark$ & 10 \\
\hline Appearance of scientific journals on LCA & $\checkmark$ & & & & & 10 \\
\hline $\begin{array}{l}\text { Development of regional specific LCI tools and energy } \\
\text { simulation tools }\end{array}$ & $\checkmark$ & $\checkmark$ & $\checkmark$ & & $\checkmark$ & $\begin{array}{l}2,8,9,10 \\
11,12\end{array}$ \\
\hline $\begin{array}{l}\text { Increase the accuracy of LCA results by using accurate } \\
\text { LCA data instead of using deterministic values }\end{array}$ & $\checkmark$ & $\checkmark$ & $\checkmark$ & & & 1 \\
\hline $\begin{array}{l}\text { Enrich the existing literature and knowledge on LCA by } \\
\text { undertaking more LCA related research activities }\end{array}$ & $\checkmark$ & & $\checkmark$ & & & 1,5 \\
\hline $\begin{array}{l}\text { Integrate Building Information Modeling (BIM) with LCI } \\
\text { tools, energy simulation software, sensitivity analysis } \\
\text { software and Maintenance, Repair and Replacement } \\
\text { (MRR) scheduling to increase interoperability }\end{array}$ & $\checkmark$ & $\checkmark$ & $\checkmark$ & & & $4,13,14$ \\
\hline Development of Hybrid LCA frameworks and approaches & $\checkmark$ & $\checkmark$ & & & & 3 \\
\hline Provision of guidance to the LCA practitioners & $\checkmark$ & $\checkmark$ & $\checkmark$ & $\checkmark$ & $\checkmark$ & 3,5 \\
\hline Increase interest on environmental sustainability & & $\checkmark$ & $\checkmark$ & $\checkmark$ & $\checkmark$ & 5,12 \\
\hline Encourage the use of LCA tools & $\sqrt{ }$ & $\checkmark$ & $\checkmark$ & & $\checkmark$ & 5 \\
\hline $\begin{array}{l}\text { Development of LCI data bases for new innovative } \\
\text { materials }\end{array}$ & $\checkmark$ & $\checkmark$ & $\checkmark$ & & $\checkmark$ & 8 \\
\hline Commitment from top management to implement LCA & & $\checkmark$ & & & & 8 \\
\hline $\begin{array}{l}\text { Implement policy governance measures in order to } \\
\text { encourage building developers and designers to apply } \\
\text { LCA in early design stage }\end{array}$ & & & $\checkmark$ & & $\checkmark$ & 8 \\
\hline $\begin{array}{l}\text { Implementation of environmental reporting and } \\
\text { management systems }\end{array}$ & & $\checkmark$ & $\checkmark$ & & $\checkmark$ & 9 \\
\hline
\end{tabular}




\begin{tabular}{|c|c|c|c|c|c|c|}
\hline \multirow[t]{2}{*}{$\begin{array}{l}\text { Required contributions from stakeholders to establish } \\
\text { LCA for the construction industry }\end{array}$} & \multicolumn{5}{|c|}{$\begin{array}{l}\text { Responsible } \\
\text { Stakeholders }\end{array}$} & \multirow[t]{2}{*}{$\begin{array}{l}\text { Reference } \\
\text { Code }\end{array}$} \\
\hline & 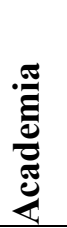 & 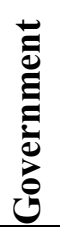 & 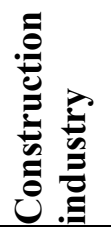 & 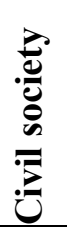 & 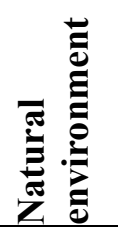 & \\
\hline $\begin{array}{l}\text { Urge the use of the Environmental Product Declarations } \\
\text { (EPD) based on LCA }\end{array}$ & $\checkmark$ & $\checkmark$ & $\checkmark$ & & $\checkmark$ & $6,7,9$ \\
\hline Use of streamlined LCA & $\checkmark$ & $\checkmark$ & $\checkmark$ & $\checkmark$ & $\checkmark$ & 9,14 \\
\hline $\begin{array}{l}\text { Provision of subsidies for the reduction of environmental } \\
\text { impacts }\end{array}$ & & $\checkmark$ & $\checkmark$ & & & $6,12,14$ \\
\hline $\begin{array}{l}\text { Development of reporting and communication mechanism } \\
\text { for LCA result }\end{array}$ & $\checkmark$ & $\checkmark$ & $\checkmark$ & & $\checkmark$ & 13 \\
\hline Development of a national open access databases & $\checkmark$ & $\checkmark$ & $\checkmark$ & & $\checkmark$ & 13 \\
\hline $\begin{array}{l}\text { Encourage eco-design of new building construction and } \\
\text { rehabilitation of existing buildings }\end{array}$ & $\checkmark$ & $\checkmark$ & $\checkmark$ & $\checkmark$ & $\checkmark$ & 7 \\
\hline
\end{tabular}

(Sources: 1- Aktas and Bilec, 2012; 2- Azari, 2014; 3- Bilec et al., 2009; 4- Bilec et al., 2006; 5- Blengini, 2009; 6- Bribián et al., 2009; 7- Bribián et al., 2011; 8- Chau et al., 2015; 9Erlandsson and Borg, 2003; 10- Grundel and Dahlstrm, 2016; 11- Khasreen et al., 2009; $12-$ Malmqvist et al., 2011; 13- Takano et al., 2014; 14- Zuo et al., 2017)

\subsection{STAKEHOLDER INVOLVEMENT TO ESTABLISH LIFE CYCLE ASSESSMENT IN CONSTRUCTION INDUSTRY}

Table 1 indicates that each stakeholder has to contribute individually or collectively to integrate LCA into construction industry. Further, there is a need for developing bilateral and multilateral relationships between stakeholders for LCA integration to the construction industry.

Accordingly, Grundel and Dahlstrm (2016) specified that promoting multidisciplinary coordination by organizing platforms to gather research bodies, industry professionals, LCA specialists and the government bodies can be identified as one of the major contribution of academia, government and building industry for the continuous improvement of LCA integration to the construction industry. Relevant environmental laws, policies and regulations required to be formulated by the government with the help of construction industry to encourage building designers and developers to apply LCA at the initial stage of building construction (Chau et al., 2015). Grundel and Dahlstrm (2016) explained regional specific LCA databases have to be developed as a collaborative process between academia, building industry, government for the purpose of enhancing credibility of LCA results. Moreover, BIM can be used to assists in information management and communication between different stakeholders throughout the project lifecycle. Integration of both BIM and LCA facilitate real time data capturing ability at any time. Hence stakeholders such as academia, government, construction industry and natural environment have to contribute their effort in integrating LCA with BIM (Zuo et al., 2017). Aktas and Bilec (2012) argued that it is important to provide priority to conduct LCA based research activities by the academia and government cooperatively. Construction industry have to be actively participated in organising workshops and 
publishing guidelines and handbooks on LCA in order to popularise and implement the LCA (Dewulf et al., 2009). Moreover, civil society, construction industry and environmentalists (natural environmnt) have to increase their interest in developing more and more green buildings. As, erection of green buildings require complete LCA to assess harmful environmental impacts during the entire lifecycle.

Hence, it can be said that the process of successful LCA integration to the construction industry is needed to create win-win situation among all related stakeholders; such as academia, construction industry, government, civil society, and natural environment. Therefore, LCA integration to the construction industry can be identified as a collaborative and disseminated innovative processes rather than simple activity. When considering Sri Lanka as a developing county numerous views emphasize that LCA implementation and adaptation has been limited in the construction industry (Edirisinghe, 2013). Even though, it has emerged as a requirement in integrating LCA concept to Sri Lankan construction industry as a solution to reduce increasing adverse environmental impacts. As, Dissanayake (2016) has revealed that $40 \%$ of GHG emission, and $30 \%$ of solid waste generation are immense contributors to the atmospheric pollution contributed by the building sector in Sri Lanka. Accordingly, for the purpose of providing better assistance to the wide-spread adoption of LCA in Sri Lankan construction industry, Figure 1 was developed based on the findings from a desk study to highlight the essential contributions from five (05) prominent stakeholders to establish LCA within Sri Lankan construction industry.

According to Figure 1, LCA integration to the construction industry consists a variety of implications that cannot be handled by a single stakeholder due to the lack of competences and resources. Hence the collaborative activities between stakeholders can be identified as a way of integrating LCA into the construction industry, as resources and capabilities are disseminated among a wide network of stakeholders (e.g. academia, industry, construction industry, society, and natural environment). Hence, stakeholders need to collaboratively act with each other for the successful LCA integration through mutual interactions.

\section{CONCLUSIONS}

Environmental issues seemingly become more complex, unpredictable and multistate, and affect a wide variety of stakeholders and demanding novel technical solutions, new collaborations and societal transformations. Consequently, LCA came into practice as a remedy to mitigate possible environmental impacts generated by the construction industry. Moreover, global environmental needs and targets of reducing adverse environmental impacts generated by the building sector can be achieved by integrating LCA with the help of main five (05) stakeholders such as; academia, government, construction industry, civil society, and the natural environment. Though, holistic assessment of LCA have been disregarded in Sri Lankan context, due to the lack of contribution from main five (05) stakeholders in the society. LCA integration to the built environment is extremely important for Sri Lankan context. As, Sri Lankan building sector is stepping into a mega building avenue in the next few years with the escalation of upcoming projects e.g. Megapolis and Port City. However, despite its major contribution to the economic growth, construction industry has generated huge environmental impacts. Hence, LCA is currently novel, essential, and trendy, concurrently. 


\begin{tabular}{|c|c|c|c|c|}
\hline 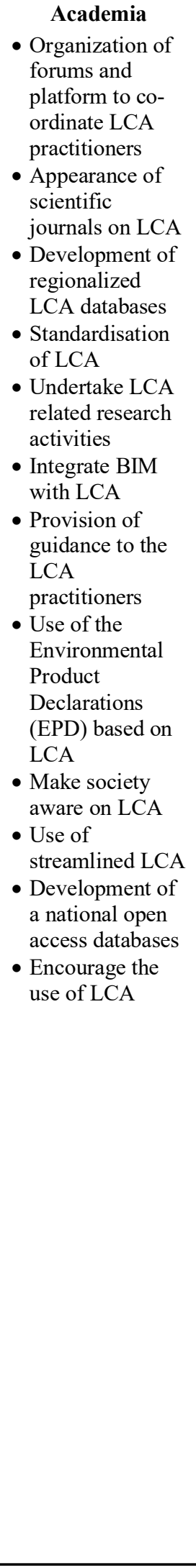 & 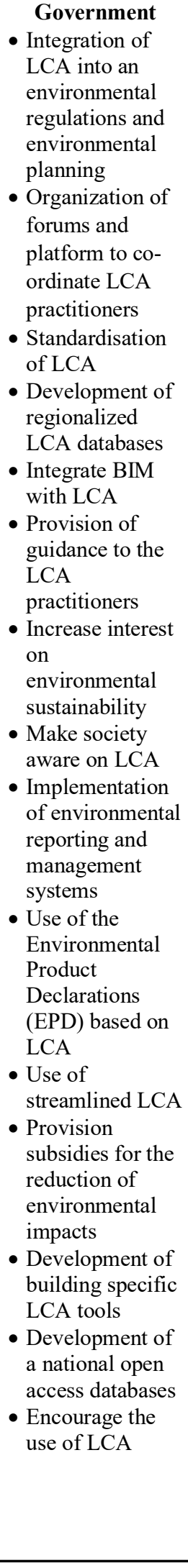 & 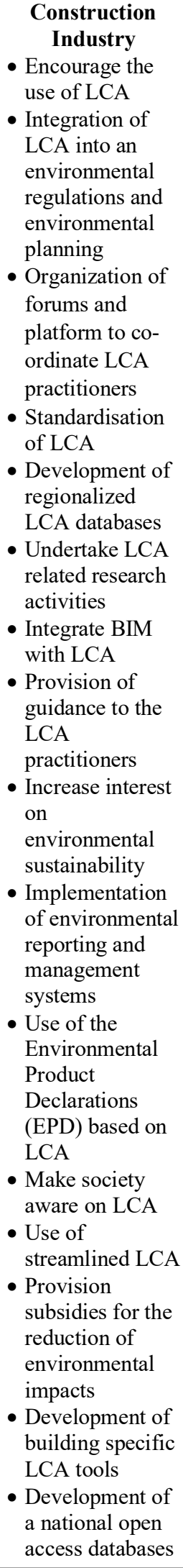 & $\begin{array}{l}\text { Civil Society } \\
\text { - Encourage the } \\
\text { use of LCA } \\
\text { - Organization of } \\
\text { forums and } \\
\text { platform to co- } \\
\text { ordinate LCA } \\
\text { practitioners } \\
\text { - Provision of } \\
\text { guidance to the } \\
\text { LCA } \\
\text { practitioners } \\
\text { - Incorporate LCA } \\
\text { into strategic } \\
\text { environmental } \\
\text { planning } \\
\text { - Increase interest } \\
\text { on } \\
\text { environmental } \\
\text { sustainability } \\
\text { - Use of the } \\
\text { Environmental } \\
\text { Product } \\
\text { Declarations } \\
\text { (EPD) based on } \\
\text { LCA } \\
\text { - Make society } \\
\text { aware on LCA }\end{array}$ & 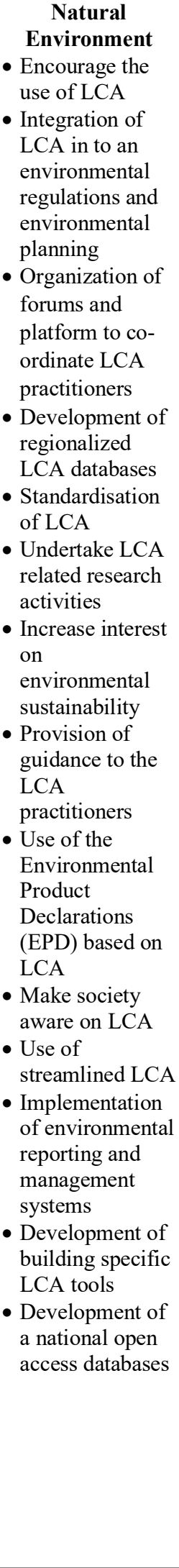 \\
\hline
\end{tabular}

Figure 1: Summary of essential contributions from stakeholders to establish LCA for the construction industry 
The outcomes of this research explain the essential contribution from the each of the related stakeholders (e.g. academia, industry, construction industry, civil society, and natural environment), which will need to drive LCA integration to the construction industry. Hence, identified essential contribution would be highly important to the domain of LCA application, since there has been lack of research in the area towards integrating LCA to Sri Lankan construction industry. Deliverables of this study can be used to understand the each of the stakeholder contribution towards the successful LCA implementation to the construction industry in Sri Lanka. Subsequently, the creation of a LCA enabled environment with the help of five (05) prominent stakeholders in the society will motivate to apply LCA as a decision making tool, to assess environmental impacts generated throughout the entire building lifecycle. Finally, it is recommended to conduct further study to identify significance of each stakeholder contribution to the LCA implementation for construction industry.

\section{ACKNOWLEDGEMENTS}

Financial support for this research was provided by the University of Moratuwa Senate Research Committee Long Term Grant No SRC/LT/2019/23.

\section{REFERENCES}

Aktas, C.B. and Bilec, M.M., 2012. Impact of Lifetime on US Residential Building LCA Results. The International Journal of Life Cycle Assessment, 17(3), pp.337-349.

Atmaca, A., 2016. Life Cycle Assessment and Cost Analysis of Residential Buildings in South East of Turkey: Part 1-Review and Methodology. The International Journal of Life Cycle Assessment, 21(6), pp.831-846.

Azari, R., 2014. Integrated Energy and Environmental Life Cycle Assessment of Office Building Envelopes. Energy and Buildings, 82, pp.156-162.

Basbagill, J., Flager, F., Lepech, M. and Fischer, M., 2013. Application of Life-Cycle Assessment to Early Stage Building Design for Reduced Embodied Environmental Impacts. Building and Environment, 60, pp.81-92.

Bilec, M., Ries, R., Matthews, H.S. and Sharrard, A.L., 2006. Example of a Hybrid Life-Cycle Assessment of Construction Processes. Journal of Infrastructure Systems, 12(4), pp.207-215.

Bilec, M.M., Ries, R.J. and Matthews, H.S., 2009. Life-Cycle Assessment Modeling of Construction Processes for Buildings. Journal of Infrastructure Systems, 16(3), pp.199-205.

Bingham, I.J., Hoad, S.P., Lang, B., Philpott, H., Stobart, R., Thomas, J., Barnes, A.P., Ball, B.C., Knight, S. and Kightley, S., 2012. Desk study to evaluate contributory causes of the current yield plateau in wheat and oilseed rape. Home Grown Cereals Authority (HGCA) Project Report No. 502.

Blengini, G.A., 2009. Life Cycle of Buildings, Demolition and Recycling Potential: A Case Study in Turin, Italy. Building and Environment, 44(2), pp.319-330.

Bribián, I.Z., Capilla, A.V. and Usón, A.A., 2011. Life Cycle Assessment of Building Materials: Comparative Analysis of Energy and Environmental Impacts and Evaluation of the Eco-Efficiency Improvement Potential. Building and Environment, 46(5), pp.1133-1140.

Bribián, I.Z., Usón, A.A. and Scarpellini, S., 2009. Life Cycle Assessment in Buildings: State-of-the-art and Simplified LCA Methodology as a Complement for Building Certification. Building and Environment, 44(12), pp.2510-2520.

Buyle, M., Braet, J. and Audenaert, A., 2013. Life Cycle Assessment in the Construction Sector: A Review. Renewable and Sustainable Energy Reviews, 26, pp.379-388.

Chau, C.K., Leung, T.M. and Ng, W.Y., 2015. A Review on Life Cycle Assessment, Life Cycle Energy Assessment and Life Cycle Carbon Emissions Assessment on Buildings. Applied Energy, 143, pp.395413. 
Crisp, D.T., 1981. A Desk Study of the Relationship between Temperature and Hatching Time for the Eggs of Five Species of Salmonid Fishes. Freshwater Biology, 11(4), pp.361-368.

Dewulf, J., Van der Vorst, G., Versele, N., Janssens, A. and Van Langenhove, H., 2009. Quantification of the Impact of the End-of-Life Scenario on the Overall Resource Consumption for a Dwelling House. Resources, Conservation and Recycling, 53(4), pp.231-236.

Dissanayake, R. 2016. Green Buildings for Sustainable Built Environment in Sri Lanka (Unpublished doctoral dissertation).

Eckerberg, K., and Nilsson, M. 2013. Environmental Policy Integration in Practice: Shaping Institutions for Learning. London, England: Routledge.

Edirisinghe, J., 2013. Life Cycle Assessment of a Ceramic Tile Produced in Sri Lanka. ARPN Journal of Science and Technology, 3(11), pp.02-12.

Erlandsson, M. and Borg, M., 2003. Generic LCA-Methodology Applicable for Buildings, Constructions and Operation Services-Today Practice and Development Needs. Building and Environment, 38(7), pp.919-938.

Fedkin, M. 2017. Technology for Sustainability Systems. Available from: http:/www.eeducation.psu.edu/eme807/node/690 [Accessed 10 April 2019].

Grundel, I. and Dahlström, M., 2016. A Quadruple and Quintuple Helix Approach to Regional Innovation Systems in the Transformation to a Forestry-Based Bioeconomy. Journal of the Knowledge Economy, 7(4), pp.963-983.

Guinee, J.B., Heijungs, R., Huppes, G., Zamagni, A., Masoni, P., Buonamici, R., Ekvall, T. and Rydberg, T., 2010. Life Cycle Assessment: Past, Present, and Future. Environmental Science \& Technology, 45(1), pp.90-96

Islam, H., Jollands, M. and Setunge, S., 2015. Life Cycle Assessment and Life Cycle Cost Implication of Residential Buildings: A Review. Renewable and Sustainable Energy Reviews, 42, pp.129-140.

Khasreen, M., Banfill, P.F. and Menzies, G., 2009. Life-Cycle Assessment and the Environmental Impact of Buildings: A Review. Sustainability, 1(3), pp.674-701.

Kogler, K. and Goodchild, R., 2006. The European Commission's Communication Integrated Product Policy: Building on Environmental Life-Cycle Thinking. Governance of Integrated Product Policy, pp.70-77.

Malmqvist, T., Glaumann, M., Scarpellini, S., Zabalza, I., Aranda, A., Llera, E. and Díaz, S., 2011. Life Cycle Assessment in Buildings: The ENSLIC Simplified Method and Guidelines. Energy, 36(4), pp.1900-1907.

Mills, E., 2011. Building Commissioning: A Golden Opportunity for Reducing Energy Costs and Greenhouse Gas Emissions in the United States. Energy Efficiency, 4(2), pp.145-173.

Ortiz, O., Castells, F. and Sonnemann, G., 2009. Sustainability in the Construction Industry: A Review of Recent Developments Based on LCA. Construction and Building Materials, 23(1), pp.28-39.

Robertson, A.B., Lam, F.C. and Cole, R.J., 2012. A Comparative Cradle-to-Gate Life Cycle Assessment of mid-rise Office Building Construction Alternatives: Laminated Timber or Reinforced Concrete. Buildings, 2(3), pp.245-270.

Rønning, A. and Brekke, A., 2014. Life Cycle Assessment (LCA) of the Building Sector: Strengths and Weaknesses. Eco-Efficient Construction and Building Materials (pp.63-83). Woodhead Publishing.

Saunders, C. L., Landis, A. E., Mecca, L. P., Jones, A. K., Schaefer, L. A., and Bilec, M. M. 2013. Analyzing the Practice of Life Cycle Assessment: Focus on the Building Sector. Journal of Industrial Ecology, 17(5), pp.777-788.

Singh, A., Berghorn, G., Joshi, S. and Syal, M., 2010. Review of Life-Cycle Assessment Applications in Building Construction. Journal of Architectural Engineering, 17(1), pp.15-23.

Szalay, Z., 2007. Life Cycle Environmental Impacts of Residential Buildings (Unpublished doctoral dissertation). Budapest University of Technology and Economics, Hungary.

Takano, A., Winter, S., Hughes, M. and Linkosalmi, L., 2014. Comparison of Life Cycle Assessment Databases: A Case Study on Building Assessment. Building and Environment, 79, pp.20-30.

Zhang, Z., Provis, J.L., Reid, A. and Wang, H., 2014. Geopolymer foam Concrete: An Emerging Material for Sustainable Construction. Construction and Building Materials, 56, pp.113-127. 
Zuo, J., Pullen, S., Rameezdeen, R., Bennetts, H., Wang, Y., Mao, G., Zhou, Z., Du, H. and Duan, H., 2017. Green Building Evaluation from a Life-Cycle Perspective in Australia: A Critical Review. Renewable and Sustainable Energy Reviews, 70, pp.358-368. 